Bird Photography

By G. K. Yeates. Pp. $114+48$ plates. Faber \& Faber, Ltd., 1946.) 12s. 6d. net.

(London :

B RD photography has now so many skilled devotees that to say Captain G. K. Yeates is among the best places him very high indeed, yet he certainly excels not only in securing subjects in happy and characteristic pose, but in the technical skill with which he renders bird and surroundings. In this book he has set forth in full and clear detail the conclusions at which he has arrived during many years work and experience, illustrating the whole with excellent reproductions of his fine pictures. The book will be read with profit and appreciation by all bird photographers, and will be invaluable to the beginner.

He discusses apparatus, hides, mothods of work, and various types of work. His remarks on cameras should save the novice much cash and grief, for as he justly points out a good bird portrait at the nest can be better achieved with an old-fashioned stand camera than the most perfect of modern miniatures, though the latter is invaluable for flight snapshotting and such subjects. But on the lens, as he rightly insists, no photographer must economize. It is interesting to note that for all-round field work he prefers an 81 -in. lens. $\mathrm{He}$ points out that, though a telephoto lens has its uses, a bird photographer can do a vast amount of good work with one useful lens. On hides, too, Captain Yeates has much that is helpful to say, whether it be a plain, simple ground hide, or one aloft in a tree, in connexion with which he shows some especially good tree-top pictures, including a most excellent portrait of a brooding rook, reminding us of the work he did some years ago on the social behaviour and home life of the rook. May we suggest it is in such intensive study that bird photography will, in the future, be of greatest assistance to ornithology.

Frances PitT

Om Nordens, Främst Baltikums, Senkvartära Utveckling och Stenåldersbebyggelse

(On the Late Quaternary Development and the Stone Age Settlement of North Europe, primarily the Baltic.) Av Henr. Munthe. (Kungl. Svenska Vetenskapsakademiens Handlingar, Serien 3, Band 19, No. 1.) Pp. $242+16$ plates. (Stockholm: Almquist and Wiksells Boktryckeri A.-B.; London: H. K. Lewis and Co., Ltd., 1940.) n.p.

$\mathrm{D}$ R. MUNTHE is a distinguished geochronologist. He must be the doyen in his subject in Scandinavia. His first paper was published so long ago as 1886, and since that date fow years have passed without some further contribution to knowledge appearing from his pen. The volume under notice presents the mature results of the author's work and conclusions on his subject. Scandinavian geochronology from the end of pleistocene times onwards is particularly complex and interesting. Not only was the region affected by the normal sequence of postglacial climate changes, but there were also up and down movements of the land relative to the sea which have to be taken into account. Dr. Munthe's exposé is largely factual, and there is a wealth of information here collected, the results of his own and other people's investigations. The treatment of the stone age settlements is slighter. The author is interested in human cultures not so much in themselves as in how they correlate with the various climate phases with which he is concerned. There are plenty of illustrations, the descriptions of which are translated into English; there are also sixteen very important maps and diagrams in a folder at the end of the volume. The book as a whole is, of course, in Swedish. Dr. Munthe is to be congratulated on having produced such a clear and detailed account of his life's work and ideas.

M. C. BurkitT

\section{A Home of Their Own}

By K. E. Barlow. Pp. 96. (London: Faber and Faber, Ltd., 1946.) 4s. 6d. net.

D. BARLOW is a physician practising in Coventry and here sets out to describe how a group of people in that devastated city have tried to seize opportunity by the forelock in developing $a_{4}$ venture similar to the now famous Peckham Health Experiment.

With the belief that "if living is to be made understandable through science, the role of the home in the life of society must be clearly understood", this group decided to form a Family Health Club. The motif of the club was to allow the residents on a housing estate to develop their neighbourhood with some such unit like the Peckham Health Centre as focus. In this book, little is said of the organisation of the club, and details are also scanty about the response of the tenants whose co-operation was invited; evaluation of the experiment must therefore await more information.

Most of the account is made up of Barlow's dissertations about the function of the home in society and contains much sound thinking and advice. Unfortunately, the author's enthusiasm loosens the brakes of control and, in his onward rush, releases much that is superficial and unsubstantiated. If he could be persuaded to condense this book to a quarter of its present size by eliminating loose writing and mere. tricious argument, he would make a contribution to sociological thought which would be timely and useful.

T. H. H.

\section{Chemical Industries}

Edited by L. Ivanovszky. Twentieth edition, enlarged and revised. Pp. xxviii +394 . (London: Leonard Hill, Ltd., 1946.) $15 s$.

MEETING this compilation for the first time, the I reviewer was at once impressed by the great amount of information it contains and somewhat disappointed by the mode of presentation. Evidently its present form has been acquired by evolution through recent editions; but it would appear that some of the individual glossaries could be combined, with a net gain to the convenience of the user: such are, for example, "Constructional Materials" and "Chemical Plant"; and "Industrial Chemicals", "Fine Chemicals", "Pharmaceuticals" and "Perfum. ery Raw Materials". This suggestion would seem to have added force because of the great number of trade-names of products which the glossaries contain-a feature contributing greatly to their useful. ness. It must, however, be admitted that the 22-page "Index to Technical Data" covering all the glossaries and the intervening articles goes far to provide a simple alternative : it survived all tests the reviewer could apply.

The text has evidently been carefully prepared and shows few misprints (among which, however, are to be found references to the "shakeproof" instead of "shockproof" leads and shields of modern X-ray tubes). The book is well produced, and should be a useful work of reference for industrial chemists. 